\title{
Serotonin: A Potent Immune Cell Modulator in Autoimmune Diseases
}

\author{
Minjie Wan ${ }^{1,2}$, Lili Ding ${ }^{2,3}$, Dong Wang ${ }^{1,2}$, Jiawen Han $^{2}$ and Pujun Gao ${ }^{1 *}$ \\ ${ }^{1}$ Department of Hepatology, The First Hospital of Jilin University, Jilin University, Changchun, China, ${ }^{2}$ Central Laboratory, The \\ First Hospital of Jilin University, Jilin University, Changchun, China, ${ }^{3}$ Intensive Care Unit, The First Hospital of Jilin University, \\ Jilin University, Changchun, China
}

\section{OPEN ACCESS}

Edited by:

Carlo Riccardi,

University of Perugia, Italy

Reviewed by:

Howard A. Young,

National Cancer Institute at Frederick,

United States

Yeonseok Chung,

Seoul National University, South Korea

${ }^{*}$ Correspondence:

Pujun Gao gpj0411@163.com

Specialty section

This article was submitted to Autoimmune and Autoinflammatory

Disorders,

a section of the journal

Frontiers in Immunology

Received: 16 November 2019

Accepted: 23 January 2020

Published: 11 February 2020

Citation:

Wan M, Ding L, Wang D, Han J and Gao P (2020) Serotonin: A Potent Immune Cell Modulator in

Autoimmune Diseases.

Front. Immunol. 11:186.

doi: 10.3389/fimmu.2020.00186
Serotonin, also known as 5-hydroxytryptamine $(5-H T)$ is a signaling mediator that regulates emotion, behavior, and cognition. Previous studies have focused more on the roles of 5-HT in the central nervous system (CNS). However, 5-HT also shares a strong relationship with the pathological cases of tumor, inflammation, and pathogen infection. 5-HT participates in tumor cell migration, metastatic dissemination, and angiogenesis. In addition, 5-HT affects immune regulation via different 5-HT receptors (5-HTRs) expressed immune cells, including both innate and adaptive immune system. Recently, drugs targeting at 5-HT signaling were tested to be beneficial in mouse models and clinical trials of multiple sclerosis (MS) and inflammatory bowel disease (IBD). Thus, it is reasonable to assume that $5-\mathrm{HT}$ participates in the pathogenesis of autoimmune diseases. However, the underlying mechanism by 5-HT modulates the development of autoimmune diseases has not been fully understood. Based on our previous studies and pertinent literature, we provide circumstantial evidence for an essential role of $5-\mathrm{HT}$, especially the regulation of $5-\mathrm{HT}$ on immune cells in the pathogenesis of autoimmune diseases, which may provide a new point cut for the treatment of autoimmune diseases.

\section{Keywords: 5-HT, 5-HT receptor, autoimmune disease, immune cells, serotonin}

\section{INTRODUCTION}

Serotonin, or 5-hydroxytryptamine (5-HT) was first discovered as a vasoconstrictor. It is mainly distributed in the central nervous system (CNS), gastrointestinal (GI) tract, and platelets. About 95\% of the 5-HT in our body is synthesized in enterochromaffin (EC) cells of the GI mucosa, and the remaining $5 \%$ is produced by serotonergic neurons in the CNS (1). In peripheral tissues, many cells such as adipocytes, pancreatic $\beta$ cells, and osteoclasts synthesis 5-HT (2). Besides, $\mathrm{T}$ cells and mast cells can also produce 5-HT (3). The synthesis pathway of 5-HT contains two enzymatic steps, with tryptophan (Trp) being the primary precursor of 5-HT. Trp is first transformed to 5-hydroxytryptophan (5-HTP) under the action of tryptophan hydroxylase (TPH), including TPH1 and TPH2; most of the TPH1 is found in EC cells and TPH2 is located in the central and enteric neurons. Then, with the present of aromatic amino acid decarboxylase (AADC), 5-HTP is decarboxylated to produce 5-HT (1). Once released, 5-HT is stored and transported in platelets via serotonin reuptake transporter (SERT) and formed the dense granules through vesicular monoamine transporter 2 (VAMT2) and then released in the peripheral blood upon stimulation (such as vascular injury or pathogens) (4). 5-HT can also be absorbed into enterocytes and the vascular endothelial cells via SERT (5). Monoamine oxidase (MAO) degrades 5-HT to 5-hydroxyindoleacetic acid (5-HIAA) after its physiological function is completed (6). The synthesis and transport of 5-HT is shown in Figure 1. 


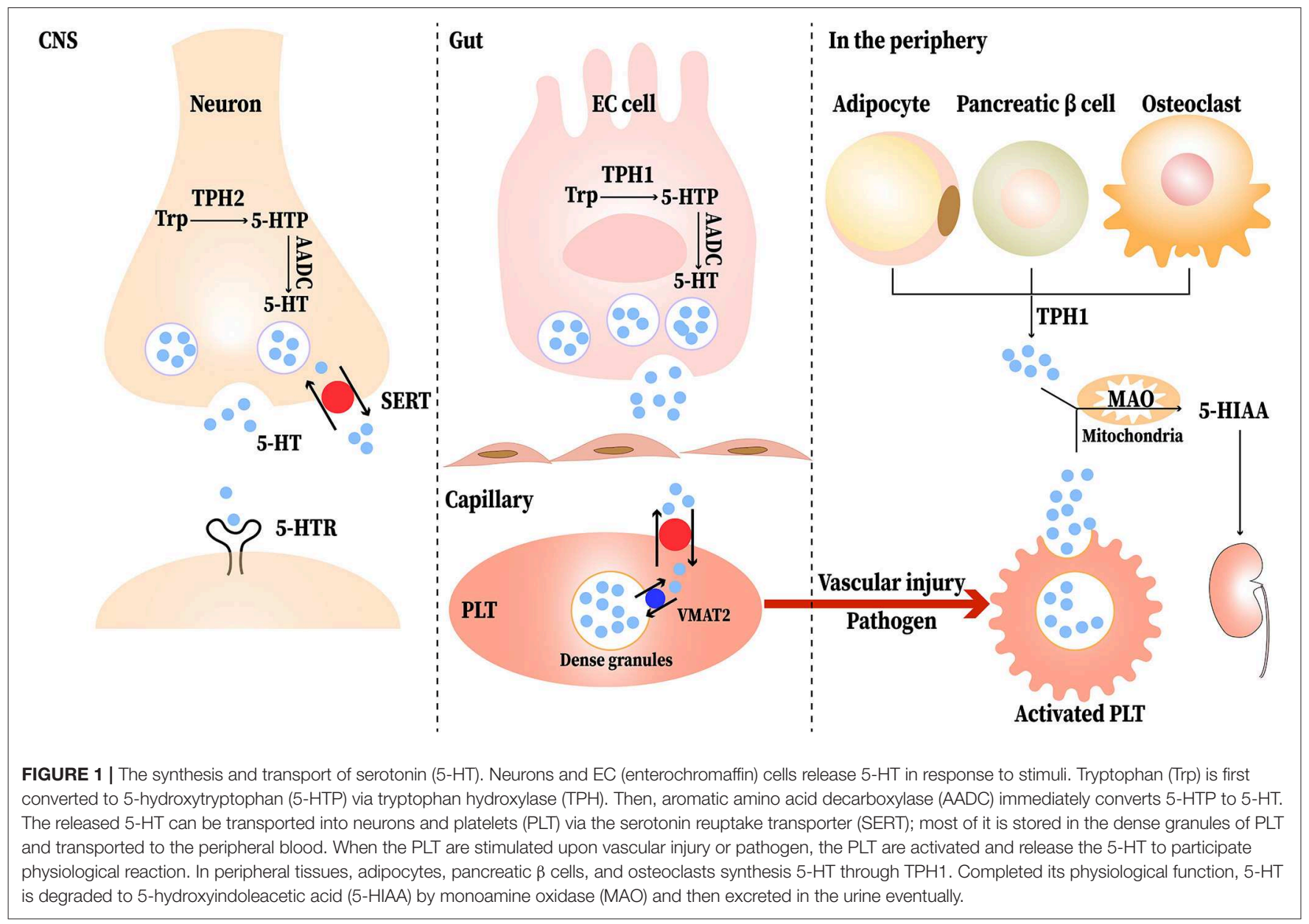

5-HT works primarily by binding to its receptors; seven families (including 15 distinct subtypes, $5-\mathrm{HT}_{1}-5-\mathrm{HT}_{7}$ ) of $5-\mathrm{HT}$ receptors have been discovered according to their different signaling mechanisms. 5-HT receptors are the G-protein coupled receptor superfamily all but $5-\mathrm{HT}_{3}$ receptor, which is the Cys-loop ligand-gated ion channel family (7). 5-HT regulates many physiological processes, such as behavior and cognition, including sleep, mood, energy balance, platelet coagulation, tissue regeneration, gastrointestinal function, and immunity (3). The functions of 5-HT in the CNS have been extensively studied, especially the pharmacological manipulations of 5-HT receptors (8). Serotonergic drugs have already been used for the treatment of several kinds of mental disorders such as depression and obsessive-compulsive disorder (9). In addition to its function in the CNS, 5-HT also plays a role in other systems. Accumulating evidence points to the role of 5 -HT in the immune system and almost all immune cells express 5-HT receptors. Table 1 lists the 5-HT receptors on different immune cells. 5-HT interacts with the innate as well as the adaptive immune system. In the course of acute inflammation, 5-HT recruits innate immune cells [immature dendritic cells (DCs), monocytes, mast cells and eosinophils, etc.] to the inflammatory site (14). In dextran sodium sulfate (DSS)-induced colitis mice, 5-HT administration increases the release of pro-inflammatory cytokines from macrophages (24). In the collagen-induced arthritis (CIA) mouse, shortage of 5-HT leads to an imbalance of $\mathrm{T}$ helper (Th) 17 and $\mathrm{T}$ regulatory cells (Tregs) and aggravation of the disease (25). $5-\mathrm{HT}_{1 \mathrm{~A}}$ receptors are more highly expressed on $\mathrm{CD}^{+} \mathrm{T}$ cells from multiple sclerosis (MS) patients, and these cells produce more 5-HT than those in healthy individuals (26, 27). Thus, 5-HT is strongly associated with immune cells in autoimmune diseases. This review intends to provide a current understanding of the roles of $5-\mathrm{HT}$ in different autoimmune diseases.

\section{DIGESTIVE SYSTEM DISEASES}

\section{Inflammatory Bowel Disease (IBD)}

IBD is a complex inflammatory disorder involving immune dysregulation for an imbalance between pro-inflammatory and anti-inflammatory signaling. Ulcerative colitis (UC) and Crohn's disease (CD) are the major types of IBD. However, the underlying etiology of IBD remains poorly understood (28). The alterations of 5-HT content in the chronic mucosa in both UC and CD have been controversial. Some studies have reported a decrease in 5-HT content, but other experiments have concluded opposite results (29-31). This difference may be related to the degree of 
TABLE 1 | The expression of 5-HT receptors on immune cells.

\begin{tabular}{|c|c|c|}
\hline Type & Family and subtype & References \\
\hline Basophils & unknown & \\
\hline B Cells & $1 \mathrm{~A} 2 \mathrm{~A} 37$ & (10) \\
\hline DC & 1B 1E 2A 2B 347 & $(11,12)$ \\
\hline Eosinophils & 1A 1B 1E 2A 2B 6 & $(13)$ \\
\hline Mast cell & $1 \mathrm{~A}$ & $(14)$ \\
\hline Macrophages & 1A 1B 1E 2A 2B 2C 347 & $(15-17)$ \\
\hline Monocytes & 1E $2 \mathrm{~A} 347$ & $(17)$ \\
\hline Neutrophils & 7 & (3) \\
\hline NK & $1 \mathrm{~A} 2 \mathrm{~A} 2 \mathrm{~B} 2 \mathrm{C}$ & $(18,19)$ \\
\hline T Cells & 1A 1B 2 A 37 & $(20-22)$ \\
\hline Platelets & $2 \mathrm{~A} 3$ & (23) \\
\hline
\end{tabular}

mucosal damage. The EC cell population is decreased in severe UC samples compared with that in the non-severe UC group and healthy controls, with there being no difference between the non-severe group and healthy group. Moreover, 5-HT levels are positively correlated with EC cell counts in colonic mucosa biopsies of patients with UC (32). Thus, the changes in 5HT levels and EC cell numbers in the mucosa in IBD could not be ascertained and depend on the severity of the mucosal damage. These above studies clearly show changes in 5-HT and EC cell levels in the mucosa during the inflammation in IBD; however, it is unclear whether their alterations play any role in gut inflammation.

5-HT may be critical for aggravating symptoms in IBD, including diarrhea and abdominal pain (33). Intraperitoneal administration of 5-HT significantly increases the expression of interleukin (IL)- $1 \beta$ and IL-6 and the activity of myeloperoxidase (MPO) by activating $5-\mathrm{HT}_{3}$ and $5-\mathrm{HT}_{4}$ receptors in colonic mucosa of colitis mice, while blocking the signal can reduce the pain (34). In TPH1 deficient colitis mice, the severity of colitis and the level of IL-1 $\beta$, IL-6, and tumor necrosis factor (TNF)- $\alpha$ was clearly reduced, and reloading 5 -HT increased the severity of DSS-induced colitis (1). A further study reported that 5 -HT increased the expression of IL-6, IL- 8 and the production of monocyte chemoattractant protein-1 (MCP-1), which lead to the initial events of gut inflammation (35). Thus, 5-HT increased pro-inflammatory cytokine levels in colitis mucosa and exacerbated abdominal pain and colitis in DSS-induced mice. As for the regulation of 5-HT in immune cells, a study by Khan and Ghia demonstrated that 5-HT stimulates macrophages to produce pro-inflammatory cytokines (24). 5-HT also activates dendritic cells (DCs) to produce more IL-12p40 through the NF$\kappa \mathrm{B}$ pathway in the colon of DSS-induced colitis mice, which results in the sequentially increased production of IL-17 and interferon (IFN) $-\gamma$ by T cells (36). Therefore, 5 -HT may play a pro-inflammatory role in the gut which activates DCs, induces T-cell proliferation, sustains immune-cell recruitment, and upregulates pro-inflammatory cytokine production. Conversely, some studies have demonstrated that 5 -HT works as an antiinflammatory molecule in the GI tract. It has been found that administrating $5-\mathrm{HT}_{4}$ receptor antagonist aggravates disease severity in DSS-induced mice, and the histological damage in the colons of $5-\mathrm{HT}_{4}$ receptor-deficient mice is more severe than that in the control group. The reason may be that the activated $5-\mathrm{HT}_{4}$ receptors can increase epithelial proliferation, promote wound healing, and improve resistance to oxidative stress-induced apoptosis (37). Additionally, $5-\mathrm{HT}_{2 \mathrm{~A}}$ receptors were upregulated in the colons of DSS-induced mice, especially in macrophages. A selective $5-\mathrm{HT}_{2 \mathrm{~A}}$ receptor antagonist, ketanserin, inhibited the expression of $\mathrm{CD} 32$ and production of inducible nitric oxide synthase (iNOS) and IL-12 in LPS-macrophages upon LPS challenge, whereas the expression of CD206 and production of IL-10 was increased. This points out that ketanserin may influence macrophages by promoting their anti-inflammatory function and promoting the shift from M1 to M2 through 5$\mathrm{HT}_{2 \mathrm{~A}}$ receptors to exert a protective function (38). Besides, 5HT receptor antagonists can restrain the production of IL- $1 \beta$ and IL-6 from DCs and alleviate the experimental intestinal inflammation (39). Overall, activation of the 5-HT signaling pathway in the gut has a pro-inflammatory effect and inhibition has an anti-inflammatory effect, but each receptor has a different effect. This functional difference in 5-HT may be due to the diversity of receptors in the GI tract. 5-HT receptors (including $5-\mathrm{HT}_{1}, 5-\mathrm{HT}_{2}, 5-\mathrm{HT}_{3}, 5-\mathrm{HT}_{4}$, and $5-\mathrm{HT}_{7}$ receptors) have been shown to be expressed in the gut (3). Additionally, the function of one type of receptor expressed on different cells such as epithelial or immune cells may be totally different. At the same time, there is a shortage of studies involving the depletion or knockout of a subtype of 5-HT receptor on different immune cells; hence, the role of the 5-HT receptors on different immune cells in a disease state cannot be defined. The pro-inflammatory and antiinflammatory roles of the 5-HT signaling pathway in IBD are shown in Figure 2.

\section{Type 1 Diabetes (T1D)}

$\mathrm{T} 1 \mathrm{D}$ is an autoimmune disease characterized by blood sugar and insulin dysregulation caused by autoimmune damage to the $\beta$ cells of the pancreatic islets (40). In the non-obese diabetic (NOD) mice, blood 5-HT levels are elevated at 6 weeks after T1D onset and are maintained at high level at all time-points (41). 5 -HT can be produced by pancreatic $\beta$ cells, which complicates the relationship between 5-HT and T1D (42). In T1D, the 5-HT signaling pathway promotes the function and proliferation of $\beta$ cells. Notably, 5-HT increases the proliferation of the pancreatic $\beta$ cells in rat insulinoma, and inhibition of 5-HT synthesis blocks $\beta$ cell expansion (40). Aside from that, the roles of 5-HT in pancreatic islets are diverse. 5-HT enhances $\beta$ cells to secrete more insulin by activating $5-\mathrm{HT}_{2}$ receptors and $5-\mathrm{HT}_{3}$ receptors. However, the opposite effect of activating $5-\mathrm{HT}_{1 \mathrm{D}}$ receptors has been reported in healthy human islets and cell lines of $\beta$ cells, which inhibits insulin secretion (42-44). Thus, the function of 5HT depends not only on its amount, but also on the receptors it binds. In a hypermetabolic condition such as pregnancy, the increase in $\beta$ cell mass is due to the prolactin-dependent pathway to induce the expression of TPH1 in $\beta$ cells, leading to increased production of 5-HT. Then 5-HT activates the intrinsic $5-\mathrm{HT}_{2 \mathrm{~B}}$ receptors and $5-\mathrm{HT}_{3}$ receptors on $\beta$ cells by autocrine or paracrine signals, leading to $\beta$ cell proliferation $(45,46)$. Although 


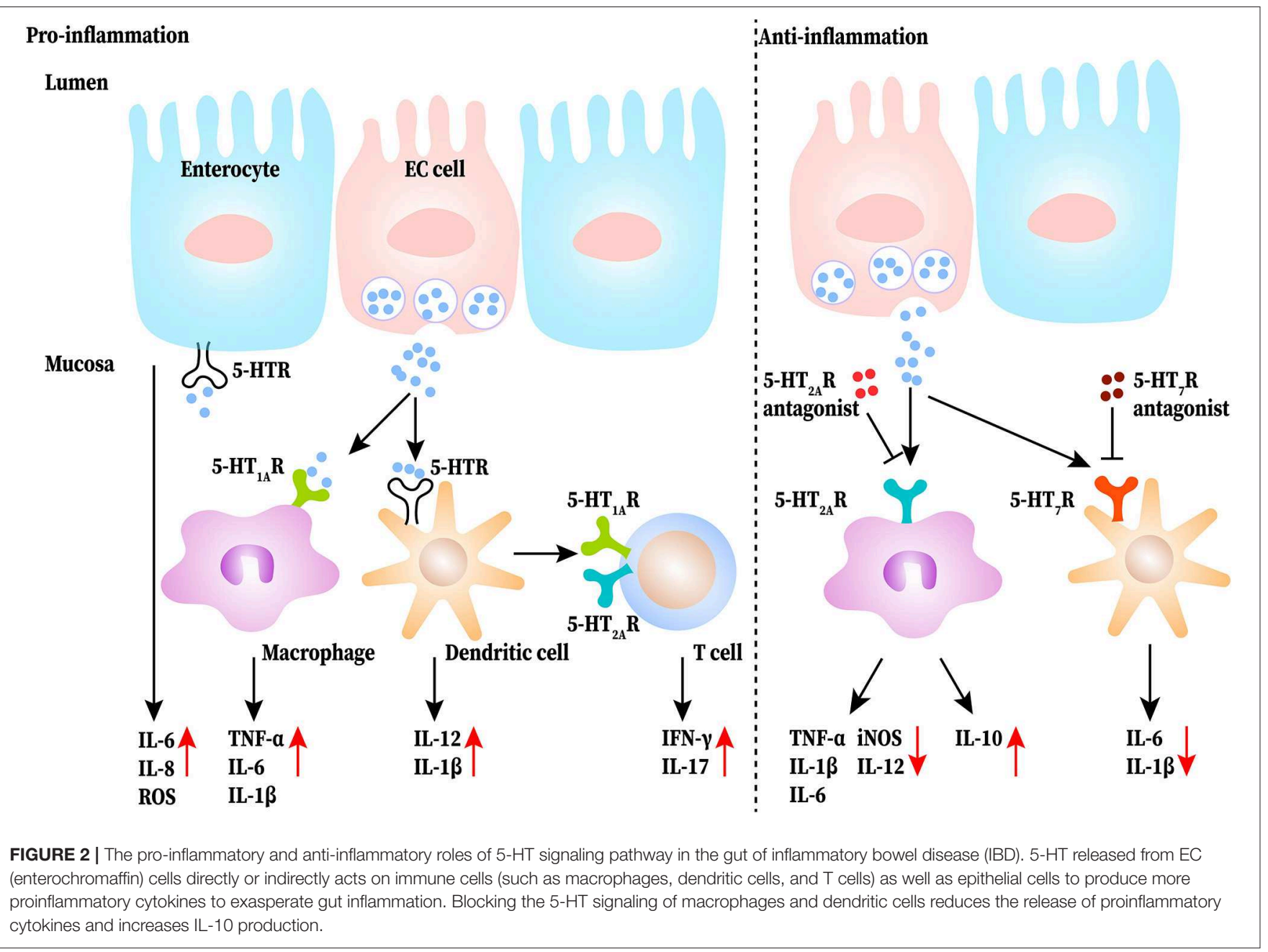

5-HT can interact with $\beta$ cells directly, the connection between 5 -HT and immune cells in T1D is very few. A selective 5$\mathrm{HT}_{2 \mathrm{~A}}$ receptor antagonist, sarpogrelate hydrochloride, reduced macrophages infiltration and down-regulated the expression of NOS2 and TNF- $\alpha$ in diabetes mice (47). Whether 5-HT is associated with the release of pro-inflammatory cytokines released from another immune cells that infiltrate the pancreas in TID needs further study.

Type 2 diabetes (T2D) is a chronic metabolic disease accompanied with insulin resistance and glucoregulatory, usually associated with obesity (48). However, with the further understanding of T2D, considerable evidences point that T2D also had autoimmune components, such as IgG antibodies related to insulin resistance and autoantibodies against pancreatic islets $(49,50)$. In the early stage of obesity, macrophages and $\mathrm{T}$ cells are elevated in adipose tissue. Macrophages and the adaptive immune system are activated even in the absence of pathogenic threat (51). Persistent chronic inflammation in adipose tissue, which in turn promotes inflammation of the systemic system and affects insulin function. Infiltration of macrophages and $\mathrm{T}$ cells are found in the islets of T2D $(52,53)$. To our knowledge, the treatment of SSRIs increases the risk of T2D in depressed patients for SSRIs reducing insulin secretion and increasing insulin dependence (54). A study reported that SSRIs exposure increased ROS and oxidative damage of $\beta$ cells (55). These strongly suggest that alterations in 5-HT signaling affect T2D disease progression. A Metaanalysis revealed that the risk of T2D in adolescents treated with SSRIs was significantly higher than that in healthy control and psychiatric controls who have not been exposed to SSRIs (56). However, a prospective clinical trial elucidated that T2D patients with depression received sertraline (a type of SSRIs) had lower body weight, body mass index, and waist circumference than those who did not receive treatment (57). Thus, it is optimal to balance the benefits of SSRIs therapy with the increased risk of T2D. And routine indicators such as blood glucose and body weight should be monitored regularly.

\section{Primary Biliary Cholangitis}

$\mathrm{PBC}$ is an immune-mediated bile duct destruction and cholestasis, which ultimately leads to liver injury, fibrosis, and cirrhosis. It's the most common chronic cholestatic autoimmune liver disease (58). In animal models of cholestasis with bile duct ligation (BDL), chronic thrombocytopenia aggravates liver 
fibrosis caused by BDL. Since 5-HT is released by platelets, the same effect can be seen with reduced plasma 5 -HT levels $(59,60)$. In detail, TPH1-deficient mice exhibit higher levels of serum aspartate aminotransferase (AST), alanine aminotransferase (ALT), bile salts, and hepatic necrosis than the WT mice in BDL. But the bile salt reabsorption transporters Osta and $O s t b$ are up-regulated in the kidneys in TPH1-deficient mice. 5 -HT is proposed to down-regulate Osta and Ostb in the kidneys, causing a decrease in toxic bile salts in the plasma and reducing liver injury (59). Another experiment demonstrated that cholangiocytes express 5-HT receptors as well as TPH2. Cholangiocytes produce 5-HT and inhibit their own growth, but stimulate liver myofibroblasts to produce transforming growth factor (TGF)- $\beta 1$. Increased TGF- $\beta 1$ suppresses cholangiocyte growth by inhibiting TPH 2 expression in an autocrine manner. In BDL mice with incomplete TPH2 function display reduced biliary 5-HT levels and excessive cholangiocyte proliferation, accumulation of aberrant ductule and liver progenitors, and more severe liver fibrosis, indicating the modulation of cholangiocytes' 5 -HT synthesis plays a crucial role in remodeling damaged bile ducts (61). Overall, platelet-derived 5-HT can suppress cholestatic liver injury and biliary fibrosis $(59,62)$. The number of mast cells which release $5-\mathrm{HT}$ is increased in the skin of PBC (63). A study of BDL rats demonstrated that 5-HT released by mast cells devoted to cholestasis pruritus and 5$\mathrm{HT}_{3 \mathrm{~A}}$ receptor antagonist ondansetron significantly relieved itching symptoms (64). In addition, several clinical trials have observed that ondansetron or SSRIs can be used to alleviate cholestatic itching (65). In the early stage of PBC, NK cell killing activity is enhanced, and monocytes and macrophages have a high response to pathogen-associated antigens (66). Then, Th1 cells and cytotoxic T lymphocyte are activated (67, 68). Furthermore, autoreactive B cells secrete large amount of antimitochondrial antibodies (69). In the final phase, the Th1 reaction shifts to Th17 (70). However, the modulation of these immune cells in the pathological process by $5-\mathrm{HT}$ to exert influence on $\mathrm{PBC}$ progression is unknown and needs further research.

\section{RHEUMATIC DISEASES \\ Rheumatoid Arthritis (RA)}

RA is a chronic autoimmune inflammatory disease with typical characteristics of chronic inflammation and joint damage (71). Activated platelets and increased serum levels of 5-HT have been reported; high levels may be a negative predictor of bone mineral density in RA for suppressing osteoblasts (72). It has been demonstrated that 5 - $\mathrm{HT}$ activates $5-\mathrm{HT}_{1 \mathrm{~B}}$ receptors on osteoblasts and inhibits their proliferation by activating proteinkinase A and cAMP-response element binding protein signaling pathway (73). Except for serum, 5-HT increases in RA synovial fluid (74). In the general population, use of SSRIs is related to a higher risk of fractures in patients with RA (75). Therefore, there might be a strong connection between 5-HT and RA. In the CIA mouse model, the content of 5-HT in the paw is increased. Meanwhile, joint inflammation and erosion, bone resorption and osteoclast differentiation, and release of pro-inflammatory factors such as TNF- $\alpha$, are all promoted in $\mathrm{Tph}^{-/-}$CIA mice (25). In addition to the alteration in local tissues, 5-HT also changes in the hippocampus in the CIA mice because the SERT activity increases and the absorption of 5-HT enhances (76).

Selective $5-\mathrm{HT}_{3}$ receptor antagonists can alleviate arthritic pain and inflammation. In the in vitro culture of macrophage-like synovial cells from osteoarthritis (OA), tropisetron can absolutely inhibit 5-HT-induced $\mathrm{PGE}_{2}$ release (77). In monocyte in vitro cultures from the peripheral blood of healthy donors, the release of TNF- $\alpha$ and IL- $1 \beta$ have been strongly suppressed by tropisetron (78). These data might account for the anti-inflammatory effect of $5-\mathrm{HT}_{3}$ receptor antagonists. Further, the role of $\mathrm{T}$ cells in RA has also been reported. Chabbi-Achengli and Comnan indicated that the levels of TNF- $\alpha$ and IFN- $\gamma$ were increased as well as the level of IL-4 was decreased in TPH1-deficient CIA mice, thus implying a stronger Th1 response. Moreover, the population of Th17 cells increased while that of Tregs decreased in the lymph nodes of CIA mice, and lack of 5-HT caused relative conversion of Tregs to Th17 cells (25). Anti-TNF therapy has been effective in RA, but the treatment of anti-TNF non-responders still remains a challenge. Considering that 5-HT are able to regulate the Th17/Tregs cell balance, the development of therapeutic approaches targeting 5-HT or 5-HT receptors is expected to be a potential prospect for modulating the immune response to RA.

\section{Systemic Sclerosis (SSc)}

SSc is an autoimmune disease characterized by chronic, progressive fibrosis, which affecting the skin and several internal organs, accompanied by abnormal activation of the immune system $(79,80)$. Plasma 5 -HT content is increased in SSc has been reported (81). Another study revealed that intraplatelet 5HT content is decreased in patients with diffuse SSc compared with that in patients with limited SSc and normal individuals (82). This indicates that the type of SSc also affects the distribution of 5-HT. As previously reported, endothelial cell injury, immune activation, and fibrosis were crucial points in the pathogenetic process of SSc, and 5-HT signaling has been reported to be involved in the pathogenesis of fibrosis, especially the $5-\mathrm{HT} / 5-\mathrm{HT}_{2 \mathrm{~B}}$ receptor signaling in skin fibrosis (83). Evidently, TGF- $\beta$ is the most crucial regulatory factor in the pathological fibrosis process of SSc (84). Upon culturing skin fibroblasts with 5-HT from healthy individuals and those with SSc, it was found that 5-HT promoted extracellular matrix proliferation in both conditions through the TGF- $\beta$ dependent pathway by activating $5-\mathrm{HT}_{2 \mathrm{~B}}$ receptors, whereas dermal thickening was found to be attenuated with $5-\mathrm{HT}_{2 \mathrm{~B}}$ receptor signaling pathway inhibitors (83). The same conclusion was made in another study. 5-HT administration up-regulated profibrotic genes and collagen production, and treatment with $5-\mathrm{HT}_{2}$ receptor and $5-\mathrm{HT}_{2 \mathrm{~B}}$ receptor antagonists reversed the attenuation of TGF- $\beta 1$ associated gene expression and collagen production (85).

In addition to the above findings, immune factors, including $\mathrm{T}$ cells and $\mathrm{B}$ cells, also involve in SSc (86). Effector $\mathrm{T}$ cells in SSc are thought to be skewed in a Th2 pattern and 
key profibrotic mediators (IL-4, IL-6, IL-13) secreted by Th2 cells are a major cause of the fibrosis in SSc (87). However, whether 5-HT affects the course of the disease by affecting immune cells has not yet been reported. Murine basophils were found to participate in the Th2 polarization by instantly secreting lots of IL-4, whereas 5-HT could downregulate this IL4 production by basophils in vitro and in vivo (88). Therefore, we hypothesized that 5-HT might inhibit the polarization of $\mathrm{T}$ cells to Th2 cells and play an anti-fibrotic role in SSc. This could also explain why Th1 polarization is predominant in most autoimmune diseases, whereas Th2 polarization is predominant in SSc. Further validation by experimental studies is needed.

\section{Systemic Lupus Erythematosus (SLE)}

SLE is an autoimmune rheumatic disorder characterized by multi-system and multi-organ lesions. Inflammation invading sites include the skin, joints, kidneys, and brain (89). The function of 5-HT in the pathogenesis of SLE is currently unclear in spite it's considerable inflammatory effects. The involvement of platelet activation and 5-HT released in SLE pathogenesis has been confirmed (90). A previous study has suggested that decreased platelet size is associated with disease activity in SLE, as activated platelets release several soluble factors, including 5HT (91). In SLE patients, a study revealed that the 5-HT content decreased in the platelets and increased in plasma, and that these levels are correlated with severity of the disease (92). However, Lood and Tydén demonstrated that the level of 5-HT in both platelets and serum are decreased and no association is found between serum 5-HT levels and clinical disease activity (90). This difference may be related to the patients' disease activity. The recruited SLE patients in the latter study were very few and there were in the inactive period at the time of blood sampling. Also, it may be associated with the activity of indoleamine 2,3dioxygenase (IDO) (IDO can deprive the ability of Trp for 5HT synthesis in favor of kynurenine). To support this view, the latter study found that plasmacytoid dendritic cells (pDC) induce large amounts of INF- $\alpha$, which can increase the expression of IDO and cause the drop of 5-HT in SLE. As for the interaction between 5-HT and immune cells, another study showed that hypomethylation of the $5-\mathrm{HT}_{1 \mathrm{~A}}$ receptor promoter region and high expression of $5-\mathrm{HT}_{1 \mathrm{~A}}$ receptors in the peripheral blood lymphocytes increase the 5-HT level in plasma and lead to the proliferation of $\mathrm{T}$ and $\mathrm{B}$ cells, which accounts for the process of SLE (21). Similar to other rheumatic diseases, 5-HT is mainly derived from platelets, which plays a role in SLE. But studies on 5HT in SLE have been limited. This may be related to the disease characteristics of SLE itself. SLE is a disease involving multiple organs, which is not limited to any one site, and is not mainly manifested by the involvement of any one organ.

\section{CENTRAL NERVOUS SYSTEM DISEASES}

\section{Multiple Sclerosis (MS)}

MS is a multiple-site-affected and relapse-remitting alternating disease of the CNS, characterized by myelin and axonal damage (93). Its main features are increased physical disability, cognitive impairment, chronic neuropathic pain, and depression (94). An interesting study showed increased susceptibility of MS in adulthood at high latitudes; it was discovered that the intake of Trp is lower in the high-latitude area than in normal conditions. Lower Trp leads to a decrease of 5-HT resulting in an increased susceptibility of MS; this suggests a potential link between 5-HT and MS (95). In experimental autoimmune encephalomyelitis (EAE) mice, 5-HT content is lower than that in the WT (96). Treating with SSRIs or increasing 5-HT attenuates disease severity, and it is associated with impaired $\mathrm{T}$ cell proliferation, lower inflammatory infiltration and IFN- $\gamma$ production (97). T cells, as wells as macrophages and DCs cells, are generally accepted as the main effectors in MS pathogenesis (26). Higher expression of $5-\mathrm{HT}_{1 \mathrm{~A}}$ receptors in $\mathrm{CD}^{+} \mathrm{T}$ cells has been detected, which leadings to a 5 -HT stimulated increase in IL-10 production by $\mathrm{CD}^{+} \mathrm{T}$ cells in MS patients $(26,27)$. In vitro, 5 -HT suppresses the release of IL- 17 and IFN- $\gamma$ by CD ${ }^{+} \mathrm{T}$ cells, both of which are neurotoxic in MS (27). Specifically, IL17 can induce local (microglia) and migrant (macrophages and DCs) cells to produce more free radicals derived from oxygen and metalloproteinase 9, all of which involved in the neuronal demyelination (98). IFN- $\gamma$ has been classically considered as the pro-inflammatory cytokine indicating destructive autoimmune $\mathrm{T}$ cell activity, including activation of the innate immune system (99). The $5-\mathrm{HT}_{3}$ receptor agonist appears to activate $\mathrm{T}$ cells and selective $5-\mathrm{HT}_{3}$ receptor antagonists attenuate disease; this protective effect is related with both reduced in vitro IL-6 and IL-17 production by $\mathrm{CD} 4{ }^{+} \mathrm{T}$ cells and lower demyelination of the spinal cord $(100,101)$. In addition to T cells, 5 -HT is able to influence macrophage polarization in MS pathological process (93). Through the $5-\mathrm{HT}_{2 \mathrm{~B}}$ receptors and $5-\mathrm{HT}_{7}$ receptors on macrophages, 5-HT makes macrophages prone to polarization to M2 macrophage by inhibition of LPS-induced pro-inflammatory cytokines and regulation of M2 and M1 polarization-related genes $(15,93)$. Besides, DCs take in and store 5-HT from the local environment and then activate $\mathrm{T}$ cells to play a pro-inflammatory role in MS (102). The interactions between 5-HT and immune cells in MS are shown in Figure 3.

Failure to properly control the expression of major histocompatibility complex (MHC) class II on astrocytes may also account to MS (103). In healthy individuals, MHC class II and B7 molecules are not expressed on astrocytes, but these two proteins are detected in the astrocytes at the edges of active MS lesions. Further study has indicated that expressions in astrocytes makes it act as a facultative APC to activate T cells in the CNS (104). Moreover, activation of astrocytic $5-\mathrm{HT}_{4}$ receptors increases the production of intracellular cAMP and inhibits the expression of IFN- $\gamma$-mediated induction of MHC class II and B7 co-stimulatory molecules of astrocytes in vitro (105). In summary, MS occurs when the content of 5-HT is reduced or its signaling pathway is inhibited in the CNS. A previous study demonstrated that platelets are activated both in the CNS and peripheral blood in MS, and they are recruited into the CNS inflammatory lesions of EAE mice (106). Therefore, we can rationally speculate that it may be the 5-HT reduction in neuronal release or the alteration of SERT expression that affects the MS process rather than the 5-HT released by platelets. 


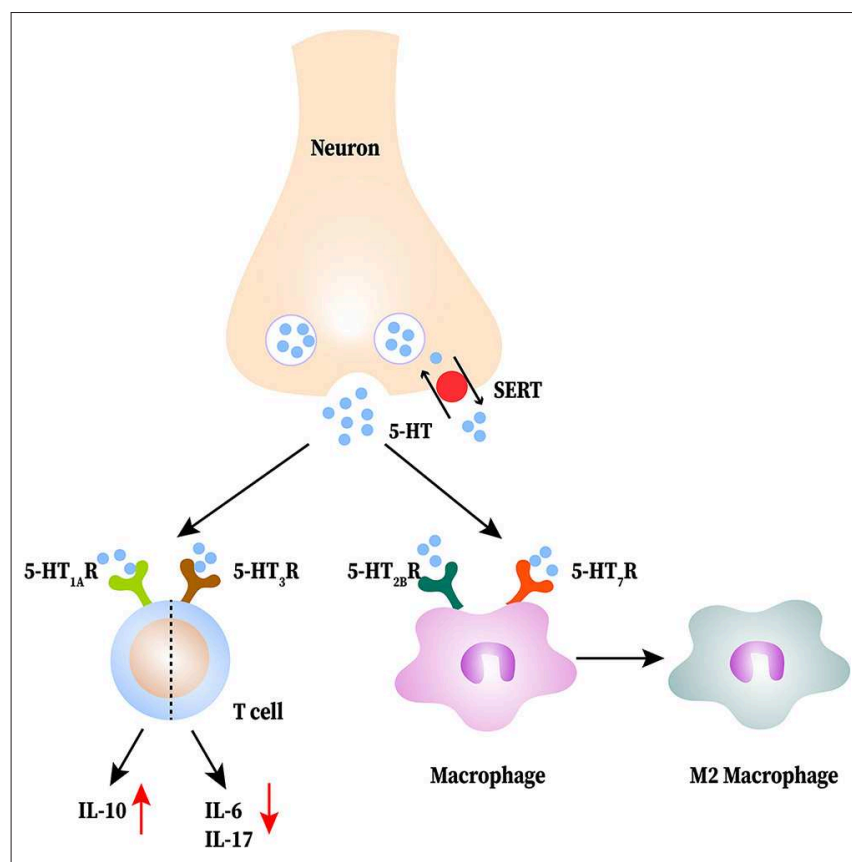

FIGURE 3 | The interactions between serotonin (5-HT) and immune cells in multiple sclerosis (MS). 5-HT released from neurons is reduced in the central nervous system (CNS). 5-HT acts on T cells to produce less proinflammatory cytokines and more IL-10. 5-HT promotes M2 macrophage polarization.

\section{OTHERS}

In addition to the diseases mentioned above, 5-HT has also been studied in other autoimmune diseases. In Hashimoto's thyroiditis mice, IDO1 and SERT are upregulated, accompanied by reduced frontal cortex 5-HT levels. This indicates that alterations in 5-HT signaling in the frontal cortex may be associated with mood control in Hashimoto's thyroiditis patients (107). In Balb/c mice of experimental antiphospholipid syndrome, nervous or mental abnormity such as cognitive deficits and hyperactivity are confirmed to be linked with the up-regulation of 5$\mathrm{HT}_{1 \mathrm{~A}}$ receptors in the hippocampal and cortical regions (108). Additionally, in the imiquimod-induced psoriasis model, mast cells and keratinocytes synthesize 5-HT (109). Further, the percentage of 5-HT-positive cells is significantly higher in skin lesions of psoriasis patients compared to that in normal skin and 5-HT recruits $\mathrm{T}$ cells to the inflammatory site of skin and enhance the ability of macrophages as an APC activate T cells (110). Meanwhile, systemic SSRIs treatment has been shown to be beneficial to psoriasis patients from a retrospective cohort study (111). Additionally, a better outcome with SSRIs treatment than placebo from a randomized controlled trial in alopecia areata has been reported (112). These evidences suggest that 5-HT plays a role in various autoimmune diseases, but type of immune cells and mechanisms need further research.

\section{Interaction Between 5-HT and Th1 and Th2}

Th1 cells are important for immunity to intracellular pathogens while Th2 cells are responsible for humoral-mediated immunity.
Both of them participate in maintaining immune homeostasis and the variation of them is found in the pathological process of autoimmune diseases (113). 5-HT acted directly on Th1 cells to reduce their production of IFN- $\gamma$ in MS patients (27). A selective $5-\mathrm{HT}_{2 \mathrm{~A}}$ receptor antagonist, sarpogrelate hydrochloride, inhibited the production of IFN- $\gamma$ by Th1 cells in a dose-dependent manner in vitro culture of mouse spleen $\mathrm{CD}^{+} \mathrm{T}$ cells, and this inhibition can be reversed by 5 $\mathrm{HT}_{2 \mathrm{~A}}$ receptor agonist (22). In addition to the direct effect, activation of $5-\mathrm{HT}_{2 \mathrm{~B}}$ receptor inhibits the polarization of human moDC-primed $\mathrm{CD}^{+}{ }^{+} \mathrm{T}$ cells toward inflammatory Th1 effector lymphocytes in inflammatory settings (114). How does 5-HT regulate Th2 is poorly studied in autoimmune diseases. But in allergic airway inflammation, lack of 5-HT leads to impaired Th2 priming capacity of DCs (115). However, the alterations of Th1 and Th2 in autoimmune diseases have not been uniformly determined, which may be due to the different subsets playing a leading role in different autoimmune diseases. CD, RA, MS, T1D and Hashimoto's thyroiditis are characterized by dominant Th1 responses while UC and SLE are a Th2-dominated response.

\section{Interaction Between 5-HT and Th17 and Tregs}

The imbalance between Th17 and Tregs has been reported in the literature on autoimmune disease (116-118). Tregs maintain self-tolerance, thereby inhibiting autoimmunity, while Th17 cells promote the induction and propagation of inflammation (116, 117). The balance between these two types of $\mathrm{CD}^{+} \mathrm{T}$ cellsone promoting inflammation, the other controlling the adaptive immune responses play an important role in autoimmune diseases (118). There is a strong association between 5-HT and these two types of cells in autoimmune diseases. In EAE mice, Th17 cells activate microglia to produce IL- 6 , IL-1 $\beta$, and TNF- $\alpha$. Then, IL- 6 inhibits the synthesis of 5 -HT by reducing tetrahydrobiopterin and TNF- $\alpha$ activates IDO, which breaks down Trp to reduce 5-HT level in the brain (119). In the in vitro culture of peripheral blood mononuclear cells isolated from MS patients, 5-HT reduces the production of IL-17 and IFN- $\gamma$ from Th17 (27).

5-HT-deficient mice displayed a relatively, dampened expansion of Tregs accompanied with an increased shift toward a Th17 phenotype in arthritis (120). Similarly, in Tph $1^{-/-}$mice of CIA, the proportion of Tregs is reduced (Foxp $3^{+} \mathrm{CD} 25^{\text {high }} \mathrm{CD} 4{ }^{+} \mathrm{T}$ cells, to be precise) and $\mathrm{Th} 17$ is increased. Reloading 5-HT can reverse the polarization of T cells to Th17 and reduce the production of IL-17 through $5-\mathrm{HT}_{2 \mathrm{~A}}$ and $5-\mathrm{HT}_{2 \mathrm{~B}}$ receptors on the surface of $\mathrm{T}$ cells. Meanwhile, 5-HT activates the $5-\mathrm{HT}_{2 \mathrm{~A}}$ receptors on $\mathrm{CD}^{+}{ }^{+} \mathrm{T}$ non-Tregs to promote Tregs proliferation (25). 5-HT upregulates regulatory marker CD39 on the surface of $\mathrm{CD} 4^{+} \mathrm{T}$ cells, increases IL-10 production, and enhances Tregs to inhibit $\mathrm{T}$ effector cells proliferation (27). After ischemic stroke, 5-HT can promote the proliferation of Tregs in the brain along with the expression of Tregs surface markers and reduce neurological dysfunction; this effect can be blocked by $5-\mathrm{HT}_{7}$ receptor antagonists (121). In addition to Th17 and Tregs, Treg 17 is a novel regulatory $\mathrm{T}$ cell 


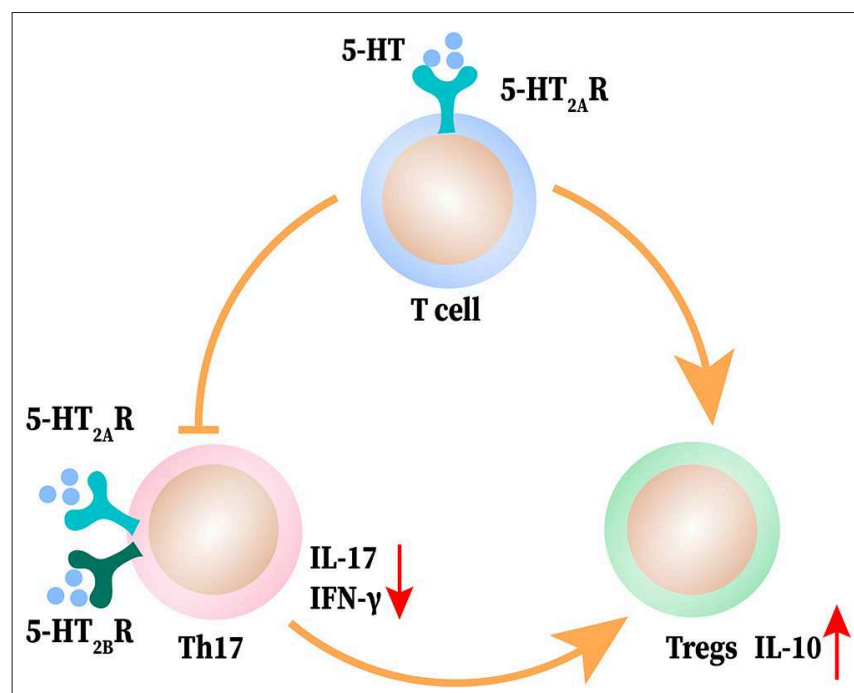

FIGURE 4 | The interaction between 5-HT and T helper (Th) 17 and T regulatory cells (Tregs). 5-HT induces T cell differentiation to Treg cells and promotes the shift of Th17 cells to Tregs. 5-HT acts on Th17 to produce less $\mathrm{IFN}-\gamma$ and IL-17 and elevates the release of IL-10 from Tregs.

subset that co-expresses IL-17 and IL-10. 5-HT up-regulates the proportion of non-classical regulatory Th17 cells (27). Overall, 5-HT can inhibit Th17 differentiation and IL-17 production, promote Tregs phenotypic expression, inhibitory capacity and proliferation, and regulate the balance of Th17/Tregs to maintain immune homeostasis in autoimmune disease and inflammatory conditions. The interactions between 5 -HT, Th17, and Tregs are shown in Figure 4.

\section{Interaction Between 5-HT and Macrophage Polarization}

Macrophage polarization plasticity is critical for maintaining tissue homeostasis. 5-HT has been reported to involved in macrophage polarization mechanisms (15). In vitro culture of human monocytes, SSRIs inhibited the release of LPS-induced pro-inflammatory cytokine. The same effect was observed with activation of $5-\mathrm{HT}_{4}$ and $5-\mathrm{HT}_{7}$ receptor on monocytes (122). Additionally, another study demonstrated that during the generation of monocyte-derived macrophages, 5-HT had this inhibitory capacity without affecting the output of IL10 , and up-regulated the M2 polarization-related gene through activating $5-\mathrm{HT}_{2 \mathrm{~B}}$ and $5-\mathrm{HT}_{7}$ receptors, which tended to express on M2 macrophage (15). In DSS-induced colitis mice, 5$\mathrm{HT}_{2 \mathrm{~A}}$ receptor was higher expressed on intestinal macrophages. With the treatment of a selective $5-\mathrm{HT}_{2 \mathrm{~A}}$ receptor antagonist, ketanserin, intestinal inflammation was alleviated, along with M2 polarization, lower pro-inflammatory cytokine production, and impaired migration of macrophage. Knockout of the 5$\mathrm{HT}_{2 \mathrm{~A}}$ receptor abrogated this anti-inflammatory effect and inhibited the NF- $\kappa \mathrm{B}$ pathway in macrophages. Therefore, 5-HT may regulate macrophage polarization through 5 -HTR2A/NF$\kappa \mathrm{B}$ (38). Considering the capacity of $5-\mathrm{HT}$ to promote M2 polarization of macrophages, inhibition of 5-HT may become a new breakthrough point in the treatment of neuroendocrine tumors (NETs). A clinical case report described telotristat (TPH inhibitor) can play an antitumor role to significantly relief the carcinoid syndrome symptoms and improve the quality of life of NETs (123). Collectively, 5-HT regulates the polarization of macrophages through multiple receptors and pathways, including both activated and inhibitory signals. In the inflammatory condition or tumor microenvironment, 5-HT promoting M2-polarization of macrophages may become a new treatment direction.

\section{CONCLUSIONS}

In spite of its recent discovery, there is accumulating evidence that 5-HT plays significant roles in autoimmune diseases. The effect of 5-HT on immune cells depends on the cell type, 5HT receptor subtype, as well as the disease itself. Due to these factors, it is difficult to define the pro- or anti-inflammatory roles of 5-HT. In this review, we build a framework linking 5HT alterations to autoimmune diseases through its effects on the immune cells. It has been confirmed that 5-HT regulates the balance of Th17/Tregs and promotes M2-polarization of macrophages and has a direct or indirect regulatory effect on traditional immunocytes such as T cells, macrophages, DC cells, and NK cells. However, little research about the interaction of 5HT and some novel immune cells has been reported. Recently, regulatory $B$ cells have attracted widespread attention for their function in autoimmune diseases such as IBD and MS (124, 125). Besides, innate lymphoid cells have been considered as regulators of immunity, inflammation, and tissue homeostasis (126). Therefore, there are several unanswered questions. For example, is 5 -HT associated with these new immune cells? Are there any undiscovered 5-HT receptor subtypes? Is the expression and distribution of 5-HT receptors on immune cells comprehensive? In the same autoimmune disease, can 5-HT acting on different immune cells have different or even opposite roles? In autoimmune diseases, can 5 -HT regulate immune cells through other receptors or pathways, besides 5-HT receptors? What are the differences in the mechanisms by which 5-HT functions in the CNS and in other systems? Elucidating these mysteries may provide a better understanding of the roles of 5-HT in autoimmune diseases.

The role of 5-HT as a neurotransmitter in the brain has been widely studied. A range of 5-HT modulating drugs such as SSRIs, monoamine oxidase inhibitors (MAOI), tricyclic antidepressants (TCA), and 5-HT norepinephrine reuptake inhibitors (SNRI) are designed to treat neurological diseases. Additionally, these drugs can also be applied in some autoimmune diseases. In a large and robust cohort, depression increased the risk of developing both CD and UC. The use of SSRIs or other antidepressants protected against CD and UC (127). It has been demonstrated that patients with IBD are more likely to suffer depression, and that depression worsens the prognosis of IBD (128). In addition to IBD, the clinical trial of fluoxetine has been carried out in secondary-progressive MS (129). Therefore, various evidences have shown that 5-HT and autoimmune 
diseases are inextricably linked. Targeting the 5-HT signaling pathway may be a new potential prospect in the treatment of autoimmune diseases.

\section{AUTHOR CONTRIBUTIONS}

MW wrote the manuscript. LD and DW consulted relevant literature. JH drew the figures. PG revised the manuscript.

\section{FUNDING}

This work was supported by a grant from the National Natural Science Foundation of China (81671592), the Science and Technology Department of Jilin Province

\section{REFERENCES}

1. Ghia JE, Li N, Wang H, Collins M, Deng Y, El-Sharkawy RT, et al. Serotonin has a key role in pathogenesis of experimental colitis. Gastroenterology. (2009) 137:1649-60. doi: 10.1053/j.gastro.2009.08.041

2. Spohn SN, Mawe GM. Non-conventional features of peripheral serotonin signalling-the gut and beyond. Nat Rev Gastroenterol Hepatol. (2017) 14:412-20. doi: 10.1038/nrgastro.2017.51

3. Shajib MS, Khan WI. The role of serotonin and its receptors in activation of immune responses and inflammation. Acta Physiol. (2015) 213:561-74. doi: 10.1111/apha. 12430

4. Jedlitschky G, Greinacher A, Kroemer HK. Transporters in human platelets: physiologic function and impact for pharmacotherapy. Blood. (2012) 119:3394-402. doi: 10.1182/blood-2011-09-336933

5. Schoenichen C, Bode C, Duerschmied D. Role of platelet serotonin in innate immune cell recruitment. Front Biosci. (2019) 24:514-26. doi: 10.2741/4732

6. Jonnakuty C, Gragnoli C. What do we know about serotonin? J Cell Physiol. (2008) 217:301-6. doi: 10.1002/jcp.21533

7. Soll C, Riener MO, Oberkofler CE, Hellerbrand C, Wild PJ, DeOliveira ML, et al. Expression of serotonin receptors in human hepatocellular cancer. Clin Cancer Res. (2012) 18:5902-10. doi: 10.1158/1078-0432.CCR-11-1813

8. Ren J, Friedmann D, Xiong J, Liu CD, Ferguson BR, Weerakkody T, et al. Anatomically defined and functionally distinct dorsal raphe serotonin subsystems. Cell. (2018) 175:472-87.e20. doi: 10.1016/j.cell.2018.07.043

9. Ohmura Y, Tsutsui-Kimura I, Sasamori H, Nebuka M, Nishitani N, Tanaka KF, et al. Different roles of distinct serotonergic pathways in anxiety-like behavior, antidepressant-like, and anti-impulsive effects. Neuropharmacology. (2019) 9:107703. doi: 10.1016/j.neuropharm.2019.107703

10. Wang SJ, Sharkey KA, McKay DM. Modulation of the immune response by helminths: a role for serotonin? Biosci. Rep. (2018) 38:1-16. doi: 10.1042/BSR20180027

11. Ahern GP. 5-HT and the immune system. Curr Opin Pharmacol. (2011) 11:29-33. doi: 10.1016/j.coph.2011.02.004

12. Baganz NL, Blakely RD. A dialogue between the immune system and brain, spoken in the language of serotonin. ACS Chem Neurosci. (2013) 4:48-63. doi: $10.1021 / \mathrm{cn} 300186 \mathrm{~b}$

13. Kang BN, Ha SG, Bahaie NS, Hosseinkhani MR, Ge XN, Blumenthal $\mathrm{MN}$, et al. Regulation of serotonin-induced trafficking and migration of eosinophils. PLoS ONE. (2013) 8:e54840. doi: 10.1371/journal.pone.0054840

14. Shajib MS, Baranov A, Khan WI. Diverse effects of gut-derived serotonin in intestinal inflammation. ACS Chem Neurosci. (2017) 8:920-31. doi: 10.1021/acschemneuro.6b00414

15. de las Casas-Engel M, Domínguez-Soto A, Sierra-Filardi E, Bragado R, Nieto C, Puig-Kroger A, et al. Serotonin skews human macrophage polarization through HTR2B and HTR7. J Immunol. (2013) 190:2301-10. doi: 10.4049/jimmunol.1201133
(20190201140JC), the National Science and Technology Major Project (2017ZX10202202, 2018ZX10302206), National Key Research Plan Precision Medicine Research Key Project (2017YFC0908103), the National Natural Science Foundation of Jilin Province (20160101097JC), Program for JLU Science and Technology Innovative Research Team (2017TD-08), and the Fundamental Research Funds for the Central Universities.

\section{ACKNOWLEDGMENTS}

We appreciated Dr. Huanfa Yi's critical comments and invaluable advice on this manuscript and Editage (www.editage.cn) for the English language editing.

16. Herr N, Bode C, Duerschmied D. The effects of serotonin in immune cells. Front Cardiovasc Med. (2017) 4:48. doi: 10.3389/fcvm.2017.00048

17. Wu H, Denna TH, Storkersen JN, Gerriets VA. Beyond a neurotransmitter: the role of serotonin in inflammation and immunity. Pharmacol Res. (2019) 140:100-14. doi: 10.1016/j.phrs.2018.06.015

18. Zimmer P, Bloch W, Kieven M, Lövenich L, Lehmann J, Holthaus M, et al. Serotonin shapes the migratory potential of NK cells-an in vitro approach. Int J Sports Med. (2017) 38:857-63. doi: 10.1055/s-0043-113042

19. Martins LC, Rocha NP, Torres KC, Dos Santos RR, França GS, de Moraes $\mathrm{EN}$, et al. Disease-specific expression of the serotonin-receptor 5-HT(2C) in natural killer cells in Alzheimer's dementia. J Neuroimmunol. (2012) 251:73-9. doi: 10.1016/j.jneuroim.2012.06.003

20. Urbina M, Arroyo R, Lima L. 5-HT7 receptors and tryptophan hydroxylase in lymphocytes of rats: mitogen activation, physical restraint or treatment with reserpine. Neuroimmunomodulation. (2014) 21:240-9. doi: 10.1159/000357148

21. Xu J, Zhang G, Cheng Y, Chen B, Dong Y, Li L, et al. Hypomethylation of the HTR1A promoter region and high expression of HTR1A in the peripheral blood lymphocytes of patients with systemic lupus erythematosus. Lupus. (2011) 20:678-89. doi: 10.1177/0961203310394892

22. Inoue $\mathrm{M}$, Okazaki $\mathrm{T}$, Kitazono $\mathrm{T}$, Mizushima $\mathrm{M}$, Omata $\mathrm{M}$, Ozaki S. Regulation of antigen-specific CTL and Th1 cell activation through 5Hydroxytryptamine 2A receptor. Int Immunopharmacol. (2011) 11:67-73. doi: 10.1016/j.intimp.2010.10.007

23. Mammadova-Bach E, Mauler M, Braun A, Duerschmied D. Autocrine and paracrine regulatory functions of platelet serotonin. Platelets. (2018) 29:54148. doi: 10.1080/09537104.2018.1478072

24. Khan WI, Ghia JE. Gut hormones: emerging role in immune activation and inflammation. Clin Exp Immunol. (2010) 161:19-27. doi: 10.1111/j.1365-2249.2010.04150.x

25. Chabbi-Achengli Y, Coman T, Collet C, Callebert J, Corcelli M, Lin $\mathrm{H}$, et al. Serotonin is involved in autoimmune arthritis through Th17 immunity and bone resorption. Am J Pathol. (2016) 186:927-37. doi: 10.1016/j.ajpath.2015.11.018

26. Montero E, Nussbaum G, Kaye JF, Perez R, Lage A, Ben-Nun A, et al. Regulation of experimental autoimmune encephalomyelitis by CD4+, CD25+ and CD8+ T cells: analysis using depleting antibodies. $J$ Autoimmun. (2004) 23:1-7. doi: 10.1016/j.jaut.2004.05.001

27. Sacramento PM, Monteiro C, Dias ASO, Kasahara TM, Ferreira TB, Hygino J, et al. Serotonin decreases the production of Th1/Th17 cytokines and elevates the frequency of regulatory CD4 T-cell subsets in multiple sclerosis patients. Eur J Immunol. (2018) 48:1376-88. doi: 10.1002/eji.2018 47525

28. Lee SH, Kwon JE, Cho ML. Immunological pathogenesis of inflammatory bowel disease. Intest Res. (2018) 16:26-42. doi: 10.5217/ir.2018.16.1.26

29. Coates MD, Tekin I, Vrana KE, Mawe GM. Review article: the many potential roles of intestinal serotonin (5-hydroxytryptamine, 5-HT) signalling in 
inflammatory bowel disease. Aliment Pharmacol Ther. (2017) 46:569-80. doi: 10.1111/apt.14226

30. Giuffrida P, Vanoli A, Biletta E, Klersy C, Bergamaschi G, Sampietro GM, et al. Increase in chromogranin A- and serotonin-positive cells in pouch mucosa of patients with ulcerative colitis undergoing proctocolectomy. Dig Liver Dis. (2018) 50:1205-13. doi: 10.1016/j.dld.2018.04.021

31. Sikander A, Sinha SK, Prasad KK, Rana SV. Association of serotonin transporter promoter polymorphism (5-HTTLPR) with microscopic colitis and ulcerative colitis. Dig Dis Sci. (2015) 60:887-94. doi: 10.1007/s10620-014-3482-y

32. Coates MD, Mahoney CR, Linden DR, Sampson JE, Chen J, Blaszyk H, et al. Molecular defects in mucosal serotonin content and decreased serotonin reuptake transporter in ulcerative colitis and irritable bowel syndrome. Gastroenterology. (2004) 126:1657-64. doi: 10.1053/j.gastro.2004.03.013

33. Minderhoud IM, Oldenburg B, Schipper ME, ter Linde JJ, Samsom M. Serotonin synthesis and uptake in symptomatic patients with Crohn's disease in remission. Clin Gastroenterol Hepatol. (2007) 5:714-20. doi: 10.1016/j.cgh.2007.02.013

34. Salaga M, Binienda A, Piscitelli F, Mokrowiecka A, Cygankiewicz AI, Verde R, et al. Systemic administration of serotonin exacerbates abdominal pain and colitis via interaction with the endocannabinoid system. Biochem Pharmacol. (2019) 161:37-51. doi: 10.1016/j.bcp.2019.01.001

35. Regmi SC, Park SY, Ku SK, Kim JA. Serotonin regulates innate immune responses of colon epithelial cells through Nox2-derived reactive oxygen species. Free Radic Biol Med. (2014) 69:377-89. doi: 10.1016/j.freeradbiomed.2014.02.003

36. Li N, Ghia JE, Wang H, McClemens J, Cote F, Suehiro Y, et al. Serotonin activates dendritic cell function in the context of gut inflammation. Am J Pathol. (2011) 178:662-71. doi: 10.1016/j.ajpath.2010.10.028

37. Spohn SN, Bianco F, Scott RB, Keenan CM, Linton AA, O'Neill CH, et al. Protective actions of epithelial 5-hydroxytryptamine 4 receptors in normal and inflamed colon. Gastroenterology. (2016) 151:933-44.e3. doi: 10.1053/j.gastro.2016.07.032

38. Xiao J, Shao L, Shen J, Jiang W, Feng Y, Zheng P, et al. Effects of ketanserin on experimental colitis in mice and macrophage function. Int J Mol Med. (2016) 37:659-68. doi: 10.3892/ijmm.2016.2486

39. Kim JJ, Bridle BW, Ghia JE, Wang H, Syed SN, Manocha MM, et al. Targeted inhibition of serotonin type 7 (5-HT7) receptor function modulates immune responses and reduces the severity of intestinal inflammation. J Immunol. (2013) 190:4795-804. doi: 10.4049/jimmunol.1201887

40. Das UN. Is there a role for bioactive lipids in the pathobiology of diabetes mellitus? Front Endocrinol. (2017) 8:182. doi: 10.3389/fendo.2017.00182

41. Buchwald P, Tamayo-Garcia A, Ramamoorthy S, Garcia-Contreras M, Mendez AJ, Ricordi C. Comprehensive metabolomics study to assess longitudinal biochemical changes and potential early biomarkers in nonobese diabetic mice that progress to diabetes. J Proteome Res. (2017) 16:3873-90. doi: 10.1021/acs.jproteome.7b00512

42. Bennet H, Mollet IG, Balhuizen A, Medina A, Nagorny C, Bagge A, et al. Serotonin (5-HT) receptor $2 \mathrm{~b}$ activation augments glucose-stimulated insulin secretion in human and mouse islets of Langerhans. Diabetologia. (2016) 59:744-54. doi: 10.1007/s00125-015-3847-6

43. Paulmann N, Grohmann M, Voigt JP, Bert B, Vowinckel J, Bader M, et al. Intracellular serotonin modulates insulin secretion from pancreatic beta-cells by protein serotonylation. PLoS Biol. (2009) 7:e1000229. doi: 10.1371/journal.pbio.1000229

44. Bennet H, Balhuizen A, Medina A, Dekker Nitert M, Ottosson Laakso E, Essén S, et al. Altered serotonin (5-HT) 1D and 2A receptor expression may contribute to defective insulin and glucagon secretion in human type 2 diabetes. Peptides. (2015) 71:113-20. doi: 10.1016/j.peptides.2015.07.008

45. Ohara-Imaizumi M, Kim H, Yoshida M, Fujiwara T, Aoyagi K, Toyofuku $\mathrm{Y}$, et al. Serotonin regulates glucose-stimulated insulin secretion from pancreatic $\beta$ cells during pregnancy. Proc Natl Acad Sci USA. (2013) 110:19420-5. doi: 10.1073/pnas.1310953110

46. Kim H, Toyofuku Y, Lynn FC, Chak E, Uchida T, Mizukami H, et al. Serotonin regulates pancreatic beta cell mass during pregnancy. Nat Med. (2010) 16:804-8. doi: 10.1038/nm.2173

47. Lee ES, Lee MY, Kwon M-H, Kim HM, Kang JS, Kim YM, et al. Sarpogrelate hydrochloride ameliorates diabetic nephropathy associated with inhibition of macrophage activity and inflammatory reaction in $\mathrm{db} / \mathrm{db}$ mice. PLOS ONE. (2017) 12:e0179221. doi: 10.1371/journal.pone.0179221

48. Della Pepa G, Vetrani C, Vitale M, Riccardi G. Wholegrain intake and risk of type 2 diabetes: evidence from epidemiological and intervention studies. Nutrients. (2018) 10:1288. doi: 10.3390/nu10091288

49. Velloso LA, Eizirik DL, Cnop M. Type 2 diabetes mellitus-an autoimmune disease? Nat Rev Endocrinology. (2013) 9:750-55. doi: 10.1038/nrendo.2013.131

50. Tsai S, Clemente-Casares X, Revelo XS, Winer S, Winer DA. Are obesityrelated insulin resistance and type 2 diabetes autoimmune diseases? Diabetes. (2015) 64:1886-97. doi: 10.2337/db14-1488

51. McLaughlin T, Ackerman SE, Shen L, Engleman E. Role of innate and adaptive immunity in obesity-associated metabolic disease. J Clin Invest. (2017) 127:5-13. doi: 10.1172/JCI88876

52. Richardson SJ, Willcox A, Bone AJ, Foulis AK, Morgan NG. Isletassociated macrophages in type 2 diabetes. Diabetologia. (2009) 52:1686-88. doi: 10.1007/s00125-009-1410-z

53. Sarikonda G, Pettus J, Phatak S, Sachithanantham S, Miller JF, Wesley JD, et al. CD8 T-cell reactivity to islet antigens is unique to type 1 while CD4 T-cell reactivity exists in both type 1 and type 2 diabetes. J Autoimmunity. (2014) 50:77-82. doi: 10.1016/j.jaut.2013.12.003

54. Noordam R, Aarts N, Peeters RP, Hofman A, Stricker BH, Visser LE. Selective serotonin reuptake inhibitors decrease pancreatic insulin secretion in older adults and increase the risk of insulin dependence in type 2 diabetes patients. J Clin Psychiatry. (2016) 77:e1124-29. doi: 10.4088/JCP.15m10048

55. De Long NE, Hyslop JR, Raha S, Hardy DB, Holloway AC. Fluoxetineinduced pancreatic beta cell dysfunction: new insight into the benefits of folic acid in the treatment of depression. J Affect Disord. (2014) 166:6-13. doi: 10.1016/j.jad.2014.04.063

56. Galling B, Roldán A, Nielsen RE, Nielsen J, Gerhard T, Carbon M, et al. Type 2 Diabetes mellitus in youth exposed to antipsychotics: a systematic review and meta-analysis. JAMA Psychiatr. (2016) 73:247-59. doi: 10.1001/jamapsychiatry.2015.2923

57. Rachdi C, Damak R, Fekih Romdhane F, Ouertani H, Cheour M. Impact of sertraline on weight, waist circumference and glycemic control: a prospective clinical trial on depressive diabetic type 2 patients. Prim Care Diabetes. (2019) 13:57-62. doi: 10.1016/j.pcd.2018.09.003

58. Carey EJ, Ali AH, Lindor KD. Primary biliary cirrhosis. Lancet. (2015) 386:1565-75. doi: 10.1016/S0140-6736(15)00154-3

59. Jang JH, Rickenbacher A, Humar B, Weber A, Raptis DA, Lehmann K, et al. Serotonin protects mouse liver from cholestatic injury by decreasing bile salt pool after bile duct ligation. Hepatology. (2012) 56:209-18. doi: $10.1002 /$ hep. 25626

60. Kodama T, Takehara T, Hikita H, Shimizu S, Li W, Miyagi T, et al. Thrombocytopenia exacerbates cholestasis-induced liver fibrosis in mice. Gastroenterology. (2010) 138:2487-98.e1-7. doi: 10.1053/j.gastro.2010.02.054

61. Omenetti A, Yang L, Gainetdinov RR, Guy CD, Choi SS, Chen W, et al. Paracrine modulation of cholangiocyte serotonin synthesis orchestrates biliary remodeling in adults. Am J Physiol Gastrointest Liver Physiol. (2011) 300:G303-15. doi: 10.1152/ajpgi.00368.2010

62. Lesurtel M, Graf R, Aleil B, Walther DJ, Tian Y, Jochum W, et al. Plateletderived serotonin mediates liver regeneration. Science. (2006) 312:104-7. doi: $10.1126 /$ science. 1123842

63. Belghiti M, Estévez-Herrera J, Giménez-Garzó C, González-Usano A, Montoliu C, Ferrer-Montiel A, et al. Potentiation of the transient receptor potential vanilloid 1 channel contributes to pruritogenesis in a rat model of liver disease. J Biol Chem. (2013) 288:9675-85. doi: 10.1074/jbc.M113.455162

64. Tian B, Wang X-L, Huang Y, Chen L-H, Cheng R-X, Zhou F-M, et al. Peripheral and spinal 5-HT receptors participate in cholestatic itch and antinociception induced by bile duct ligation in rats. Sci Rep. (2016) 6:36286. doi: $10.1038 /$ srep 36286

65. Dillon S, Tobias JD. Ondansetron to treat pruritus due to cholestatic jaundice. J Pediatr Pharmacol Ther. (2013) 18:241-46. doi: 10.5863/1551-6776-18.3.241

66. Selmi C, Lleo A, Pasini S, Zuin M, Gershwin ME. Innate immunity and primary biliary cirrhosis. Curr Mol Med. (2009) 9:45-51. doi: $10.2174 / 156652409787314525$ 
67. Zhao S-X, Li W-C, Fu N, Zhou G-D, Liu S-H, Jiang L-N, et al. Emperipolesis mediated by CD8 T cells correlates with biliary epithelia cell injury in primary biliary cholangitis. J Cell Mol Med. (2020) 24:1268-75. doi: $10.1111 /$ jcmm.14752

68. Hou X, Yang Y, Chen J, Jia H, Zeng P, Lv L, et al. TCR $\beta$ repertoire of memory $T$ cell reveals potential role for Escherichia coli in the pathogenesis of primary biliary cholangitis. Liver Int. (2019) 39:956-66. doi: 10.1111/liv.14066

69. Chung BK, Guevel BT, Reynolds GM, Gupta Udatha DBRK, Henriksen EKK, Stamataki Z, et al. Phenotyping and auto-antibody production by liver-infiltrating B cells in primary sclerosing cholangitis and primary biliary cholangitis. J Autoimmun. (2017) 77:45-54. doi: 10.1016/j.jaut.2016.10.003

70. Yang C-Y, Ma X, Tsuneyama K, Huang S, Takahashi T, Chalasani NP, et al. IL-12/Th1 and IL-23/Th17 biliary microenvironment in primary biliary cirrhosis: implications for therapy. Hepatology. (2014) 59:1944-53. doi: 10.1002/hep.26979

71. Aletaha D, Smolen JS. Diagnosis and management of rheumatoid arthritis: a review. JAMA. (2018) 320:1360-72. doi: 10.1001/jama.2018.13103

72. Bernardes M, Vieira T, Lucas R, Pereira J, Costa L, Simões-Ventura F, et al. Serum serotonin levels and bone in rheumatoid arthritis patients. Rheumatol Int. (2017) 37:1891-98. doi: 10.1007/s00296-017-3836-9

73. Galli C, Macaluso G, Passeri G. Serotonin: a novel bone mass controller may have implications for alveolar bone. J Negat Results Biomed. (2013) 12:12. doi: 10.1186/1477-5751-12-12

74. Boilard E, Blanco P, Nigrovic PA. Platelets: active players in the pathogenesis of arthritis and SLE. Nat Rev Rheumatol. (2012) 8:534-42. doi: 10.1038/nrrheum.2012.118

75. Liou YS, Lin TK, Chen HY, Jong GP. Medications associated with fracture risk in patients with rheumatoid arthritis. Ann Rheum Dis. (2019) 78:1-2. doi: 10.1136/annrheumdis-2019-216262

76. Brown E, Mc Veigh CJ, Santos L, Gogarty M, Müller HK, Elfving B, et al. TNF $\alpha$-dependent anhedonia and upregulation of hippocampal serotonin transporter activity in a mouse model of collagen-induced arthritis. Neuropharmacology. (2018) 137:211-20. doi: 10.1016/j.neuropharm.2018.04.023

77. Seidel MF, Fiebich BL, Ulrich-Merzenich G, Candelario-Jalil E, Koch FW, Vetter H. Serotonin mediates PGE2 overexpression through 5-HT2A and 5-HT3 receptor subtypes in serum-free tissue culture of macrophage-like synovial cells. Rheumatol Int. (2008) 28:1017-22. doi: 10.1007/s00296-008-0564-1

78. Fiebich BL, Akundi RS, Lieb K, Candelario-Jalil E, Gmeiner D, Haus $\mathrm{U}$, et al. Antiinflammatory effects of 5-HT3 receptor antagonists in lipopolysaccharide-stimulated primary human monocytes. Scand J Rheumatol. (2004) 119:28-32. doi: 10.1080/03009740410006998

79. The L. Systemic sclerosis: advances and prospects. Lancet. (2017) 390:1624. doi: 10.1016/S0140-6736(17)32594-1

80. Kowal-Bielecka O, Fransen J, Avouac J, Becker M, Kulak A, Allanore Y, et al. Update of EULAR recommendations for the treatment of systemic sclerosis. Ann Rheum Dis. (2017) 76:1327-39. doi: 10.1136/annrheumdis-2016-209909

81. Distler O, Cozzio A. Systemic sclerosis and localized scleroderma-current concepts and novel targets for therapy. Semin Immunopathol. (2016) 38:8795. doi: 10.1007/s00281-015-0551-z

82. Hirigoyen D, Burgos PI, Mezzano V, Duran J, Barrientos M, Saez CG, et al. Inhibition of angiogenesis by platelets in systemic sclerosis patients. Arthritis Res Ther. (2015) 17:332. doi: 10.1186/s13075-015-0848-2

83. Dees C, Akhmetshina A, Zerr P, Reich N, Palumbo K, Horn A, et al. Plateletderived serotonin links vascular disease and tissue fibrosis. J Exp Med. (2011) 208:961-72. doi: 10.1084/jem.20101629

84. Varga J, Pasche B. Transforming growth factor beta as a therapeutic target in systemic sclerosis. Nat Rev Rheumatol. (2009) 5:200-6. doi: $10.1038 /$ nrrheum.2009.26

85. Chaturvedi S, Misra DP, Prasad N, Rastogi K, Singh H, Rai MK, et al. 5-HT and 5-HT antagonists attenuate pro-fibrotic phenotype in human adult dermal fibroblasts by blocking TGF- $\beta 1$ induced non-canonical signaling pathways including STAT3: implications for fibrotic diseases like scleroderma. Int J Rheum Dis. (2018) 21:2128-38. doi: 10.1111/1756-185X.13386

86. Meng $\mathrm{M}$, Tan J, Chen W, Du Q, Xie B, Wang N, et al. The fibrosis and immunological features of hypochlorous acid induced mouse model of systemic sclerosis. Front Immunol. (2019) 10:1861 doi: 10.3389/fimmu.2019.01861

87. Korman B. Evolving insights into the cellular and molecular pathogenesis of fibrosis in systemic sclerosis. Transl Res. (2019) 209:77-89. doi: $10.1016 /$ j.trsl.2019.02.010

88. Schneider E, Machavoine F, Bricard-Rignault R, Levasseur M, PetitBertron AF, Gautron S, et al. Downregulation of basophil-derived IL4 and in vivo $\mathrm{T}(\mathrm{H}) 2$ IgE responses by serotonin and other organic cation transporter 3 ligands. J Allergy Clin Immunol. (2011) 128:864-71.e2. doi: 10.1016/j.jaci.2011.04.043

89. Durcan L, O’Dwyer T, Petri M. Management strategies and future directions for systemic lupus erythematosus in adults. Lancet. (2019) 393:2332-43. doi: 10.1016/S0140-6736(19)30237-5

90. Lood C, Tydén H, Gullstrand B, Klint C, Wenglén C, Nielsen CT, et al. Type I interferon-mediated skewing of the serotonin synthesis is associated with severe disease in systemic lupus erythematosus. PLOS ONE. (2015) 10:e0125109. doi: 10.1371/journal.pone.0125109

91. Delgado-García G, Galarza-Delgado D, Colunga-Pedraza I, Borjas-Almaguer OD, Mandujano-Cruz I, Benavides-Salgado D, et al. Mean platelet volume is decreased in adults with active lupus disease. Rev Bras Reumatol. (2016) 56:504-8. doi: 10.1016/j.rbre.2016.03.003

92. Parbtani A, Frampton G, Yewdall V, Kasai N, Cameron JS. Platelet and plasma serotonin in glomerulonephritis. III: the nephritis of systemic lupus erythematosus. Clin Nephrol. (1980) 14:164-72. doi: 10.1055/s-0039-1687048

93. Vogel DY, Vereyken EJ, Glim JE, Heijnen PD, Moeton M, van der Valk P, et al. Macrophages in inflammatory multiple sclerosis lesions have an intermediate activation status. J Neuroinflammation. (2013) 10:35. doi: 10.1186/1742-2094-10-35

94. Benito-León J, Morales JM, Rivera-Navarro J, Mitchell A. A review about the impact of multiple sclerosis on health-related quality of life. Disabil Rehabil. (2003) 25:1291-303. doi: 10.1080/09638280310001608591

95. Gong X, Xie Z, Zuo H. A new track for understanding the pathogenesis of multiple sclerosis: from the perspective of early developmental deficit caused by the potential 5-HT deficiency in individuals in high-latitude areas. Med Hypotheses. (2008) 71:580-3. doi: 10.1016/j.mehy.2008.04.026

96. Benson CA, Wong G, Tenorio G, Baker GB, Kerr BJ. The MAO inhibitor phenelzine can improve functional outcomes in mice with established clinical signs in experimental autoimmune encephalomyelitis (EAE). Behav Brain Res. (2013) 252:302-11. doi: 10.1016/j.bbr.2013. 06.019

97. Hofstetter HH, Mössner R, Lesch KP, Linker RA, Toyka KV, Gold R. Absence of reuptake of serotonin influences susceptibility to clinical autoimmune disease and neuroantigen-specific interferon-gamma production in mouse EAE. Clin Exp Immunol. (2005) 142:39-44. doi: 10.1111/j.1365-2249.2005.02901.x

98. Lovett-Racke AE, Yang Y, Racke MK. Th1 versus Th17: are T cell cytokines relevant in multiple sclerosis? Biochim Biophys Acta. (2011) 1812:246-51. doi: 10.1016/j.bbadis.2010.05.012

99. Monney L, Sabatos CA, Gaglia JL, Ryu A, Waldner H, Chernova T, et al. Th1-specific cell surface protein Tim-3 regulates macrophage activation and severity of an autoimmune disease. Nature. (2002) 415:536-41. doi: $10.1038 / 415536 a$

100. Vega Lde L, Muñoz E, Calzado MA, Lieb K, Candelario-Jalil E, Gschaidmeir $\mathrm{H}$, et al. The 5-HT3 receptor antagonist tropisetron inhibits $\mathrm{T}$ cell activation by targeting the calcineurin pathway. Biochem Pharmacol. (2005) 70:369-80. doi: 10.1016/j.bcp.2005.04.031

101. Aminian A, Noorbakhsh F, Ghazi-Khansari M, Kafami L, Javadi S, Hassanzadeh G, et al. Tropisetron diminishes demyelination and disease severity in an animal model of multiple sclerosis. Neuroscience. (2013) 248:299-306. doi: 10.1016/j.neuroscience.2013.06.009

102. Arreola R, Becerril-Villanueva E, Cruz-Fuentes C, Velasco-Velázquez MA, Garcés-Alvarez ME, Hurtado-Alvarado G, et al. Immunomodulatory effects mediated by serotonin. J Immunol Res. (2015) 2015:354957. doi: $10.1155 / 2015 / 354957$

103. De Keyser J, Zeinstra E, Frohman E. Are astrocytes central players in the pathophysiology of multiple sclerosis? Arch Neurol. (2003) 60:132-6. doi: 10.1001/archneur.60.1.132 
104. Zeinstra E, Wilczak N, Streefland C, De Keyser J. Astrocytes in chronic active multiple sclerosis plaques express MHC class II molecules. Neuroreport. (2000) 11:89-91. doi: 10.1097/00001756-200001170-00018

105. Zeinstra EM, Wilczak N, Wilschut JC, Glazenburg L, Chesik D, Kroese FG, et al. 5HT4 agonists inhibit interferon-gamma-induced MHC class II and B7 costimulatory molecules expression on cultured astrocytes. J Neuroimmunol. (2006) 179:191-5. doi: 10.1016/j.jneuroim.2006.06.012

106. Starossom SC, Veremeyko T, Yung AW, Dukhinova M, Au C, Lau AY, et al. Platelets play differential role during the initiation and progression of autoimmune neuroinflammation. Circ Res. (2015) 117:77992. doi: 10.1161/CIRCRESAHA.115.306847

107. Cai YJ, Wang F, Chen ZX, Li L, Fan H, Wu ZB, et al. Hashimoto's thyroiditis induces neuroinflammation and emotional alterations in euthyroid mice. $J$ Neuroinflammation. (2018) 15:299. doi: 10.1186/s12974-018-1341-z

108. Frauenknecht K, Katzav A, Grimm C, Chapman J, Sommer CJ. Altered receptor binding densities in experimental antiphospholipid syndrome despite only moderately enhanced autoantibody levels and absence of behavioral features. Immunobiology. (2014) 219:341-9. doi: 10.1016/j.imbio.2013.11.006

109. Sakai K, Sanders KM, Youssef MR, Yanushefski KM, Jensen L, Yosipovitch $\mathrm{G}$, et al. Mouse model of imiquimod-induced psoriatic itch. Pain. (2016) 157:2536-43. doi: 10.1097/j.pain.0000000000000674

110. Younes SF, Bakry OA. Immunohistochemical evaluation of role of serotonin in pathogenesis of psoriasis. J Clin Diagn Res. (2016) 10:ec05-9. doi: 10.7860/JCDR/2016/22692.8719

111. Thorslund K, Svensson T, Nordlind K, Ekbom A, Fored CM. Use of serotonin reuptake inhibitors in patients with psoriasis is associated with a decreased need for systemic psoriasis treatment: a population-based cohort study. $J$ Intern Med. (2013) 274:281-7. doi: 10.1111/joim.12093

112. Eskeland S, Halvorsen JA, Tanum L. Antidepressants have anti-inflammatory effects that may be relevant to dermatology: a systematic review. Acta Derm Venereol. (2017) 97:897-905. doi: 10.2340/00015555-2702

113. Raphael I, Nalawade S, Eagar TN, Forsthuber TG. T cell subsets and their signature cytokines in autoimmune and inflammatory diseases. Cytokine. (2015) 74:5-17. doi: 10.1016/j.cyto.2014.09.011

114. Szabo A, Gogolak P, Koncz G, Foldvari Z, Pazmandi K, Miltner $\mathrm{N}$, et al. Immunomodulatory capacity of the serotonin receptor 5HT2B in a subset of human dendritic cells. Sci Rep. (2018) 8:1765. doi: 10.1038/s41598-018-20173-y

115. Dürk T, Duerschmied D, Müller T, Grimm M, Reuter S, Vieira RP, et al. Production of serotonin by tryptophan hydroxylase 1 and release via platelets contribute to allergic airway inflammation. Am J Respir Crit Care Med. (2013) 187:476-85. doi: 10.1164/rccm.201208-1440OC

116. Murphy KW, Weaver C. Janeway's Immunobiology. 9th edn. New York, NY: Garland Science (2017).

117. Kamada N, Núñez G. Regulation of the immune system by the resident intestinal bacteria. Gastroenterology. (2014) 146:1477-88. doi: 10.1053/j.gastro.2014.01.060

118. Osborne LM, Brar A, Klein SL. The role of Th17 cells in the pathophysiology of pregnancy and perinatal mood and anxiety disorders. Brain Behav Immun. (2019) 76:7-16. doi: 10.1016/j.bbi.2018.11.015
119. Kant R, Pasi S, Surolia A. Auto-reactive Th17-cells trigger obsessivecompulsive-disorder like behavior in mice with experimental autoimmune encephalomyelitis. Front Immunol. (2018) 9:2508. doi: 10.3389/fimmu.2018.02508

120. Toh ML, Miossec $\mathrm{P}$. The role of $\mathrm{T}$ cells in rheumatoid arthritis: new subsets and new targets. Curr Opin Rheumatol. (2007) 19:284-8. doi: 10.1097/BOR.0b013e32805e87e0

121. Ito M, Komai K, Mise-Omata S, Iizuka-Koga M, Noguchi Y, Kondo T, et al. Brain regulatory $\mathrm{T}$ cells suppress astrogliosis and potentiate neurological recovery. Nature. (2019) 565:246-50. doi: 10.1038/s41586-018-0824-5

122. Dürk T, Panther E, Müller T, Sorichter S, Ferrari D, Pizzirani C, et al. 5Hydroxytryptamine modulates cytokine and chemokine production in LPSprimed human monocytes via stimulation of different 5-HTR subtypes. Int Immunol. (2005) 17:599-606. doi: 10.1093/intimm/dxh242

123. Molina-Cerrillo J, Grande E, Alonso-Gordoa T. Inhibition of serotonin synthesis may have antitumor activity? long-term efficacy in a patient with gastrointestinal neuroendocrine tumor. Oncologist. (2019) 24:e597-99. doi: 10.1634/theoncologist.2018-0776

124. Thi Cuc B, Pohar J, Fillatreau S. Understanding regulatory B cells in autoimmune diseases: the case of multiple sclerosis. Curr Opin Immunol. (2019) 61:26-32. doi: 10.1016/j.coi.2019.07.007

125. Wang X, Zhu Y, Zhang M, Wang H, Jiang Y, Gao P. Ulcerative colitis is characterized by a decrease in regulatory B cells. J Crohns Colitis. (2016) 10:1212-23. doi: 10.1093/ecco-jcc/jjw074

126. Klose CS, Artis D. Innate lymphoid cells as regulators of immunity, inflammation and tissue homeostasis. Nat Immunol. (2016) 17:765-74. doi: $10.1038 /$ ni.3489

127. Frolkis AD, Vallerand IA, Shaheen AA, Lowerison MW, Swain MG, Barnabe $\mathrm{C}$, et al. Depression increases the risk of inflammatory bowel disease, which may be mitigated by the use of antidepressants in the treatment of depression. Gut. (2019) 68:1606-12. doi: 10.1136/gutjnl-2018-317182

128. Potter LE, Doolen S, Mifflin K, Tenorio G, Baker G, Taylor BK, et al. Antinociceptive effects of the antidepressant phenelzine are mediated by context-dependent inhibition of neuronal responses in the dorsal horn. Neuroscience. (2018) 383:205-15. doi: 10.1016/j.neuroscience.2018. 04.047

129. Chataway J, Chandran S, Miller D, Connick P, Giovannoni G, Pavitt S, et al. The MS-smart trial in secondary progressive ms-current update. (2016) 87:e1.61-1. doi: 10.1136/jnnp-2016-315106.153

Conflict of Interest: The authors declare that the research was conducted in the absence of any commercial or financial relationships that could be construed as a potential conflict of interest.

Copyright (c) 2020 Wan, Ding, Wang, Han and Gao. This is an open-access article distributed under the terms of the Creative Commons Attribution License (CC BY). The use, distribution or reproduction in other forums is permitted, provided the original author(s) and the copyright owner(s) are credited and that the original publication in this journal is cited, in accordance with accepted academic practice. No use, distribution or reproduction is permitted which does not comply with these terms. 